\title{
Seasonal Occurrence of Western Flower Thrips, Frankliniella occidentalis (Pergande), on Table Grapes in the Hex River Valley, South Africa
}

\author{
E. Allsopp \\ ARC Infruitec-Nietvoorbij, Private Bag X5026, Stellenbosch 7599, South Africa; e-mail: allsoppe@arc.agric.za
}

Submitted for publication: November 2009

Accepted for publication: February 2010

Key words: seasonal occurrence, western flower thrips, Frankliniella occidentalis

\begin{abstract}
Western flower thrips (WFT), Frankliniella occidentalis (Pergande), on table grapes in the Hex River Valley was monitored and its seasonal occurrence was investigated over three seasons. At the start of the growing season, blue sticky traps suspended from the overhead trellising structure to hang outside and under the vine canopy yielded similar WFT numbers. However, as the season progressed and vine canopies became denser, more WFT were caught on traps hanging outside the canopy in full sunlight than on traps hanging under the vine canopy. Female WFT became active in the vineyards after bud break and their numbers increased rapidly during flowering, peaking between October and January and declining rapidly thereafter. WFT were present in pre-bloom inflorescences and shoot tips before flowering, which means that monitoring should commence as soon as the first inflorescences are formed. No consistent relationship was found between economic damage at harvest and WFT numbers on sticky traps during flowering and berry set. Sticky traps should therefore only be used to determine the presence or absence of WFT in vineyards. The trap results suggest that there could be a constant influx of thrips into vineyards from alternate host plants in the surrounding area during the growing season. In vineyards with a history of WFT damage, control measures should be considered as soon as WFT is detected in order to prevent halo spot damage.
\end{abstract}

Frankliniella occidentalis (Pergande), commonly known as western flower thrips (WFT), is native to the west coast of California (Bryan \& Smith, 1956). During the 1980s, WFT spread rapidly across the United States and through the rest of the world (Kirk \& Terry, 2003). In South Africa it was first identified on chrysanthemums near Krugersdorp in 1987, and on roses and chrysanthemums in greenhouses near Cape Town in 1988 (Giliomee, 1989). The presence of WFT and serious halo spot damage to table grape berries were first reported from the Hex River Valley in the Western Cape Province, one of South Africa's major export table grape-producing regions, during the early 1990s. This damage was consistent with halo spot oviposition damage caused by WFT on Calmeria and Italia table grape cultivars in California (Jensen, 1973). Other symptoms of WFT damage, like the reddish ring spots reported by Roditakis and Roditakis (2007), shoot stunting and leaf damage (Jensen et al., 1992), were not reported.

Prior to the introduction of WFT, thrips damage to table grapes in South Africa was sporadic and seldom resulted in economic losses, and it was attributed mainly to feeding by Thrips tabaci (Schwartz, 1987). Several other thrips species have been shown to occur on table grape leaves and flower clusters, but have not been associated with damage (Schwartz, 1988). During the 1994/1995 season, severe halo spot damage was caused to late white table grape cultivars, particularly Dauphine, and resulted in serious economic losses. This prompted the local table grape industry to commission registration trials for the chemical control of WFT (E. Jordaan, Hex River Valley Table Grape Producer's
Association, personal communication, 1995). By 2000, various products were registered for the chemical control of WFT on table grapes (Marais, 2000), although no research had been carried out on effective monitoring or on the occurrence of WFT in and around vineyards in South Africa.

In its native California, WFT occurs on a wide range of wild and cultivated host plants, overwintering mainly in the adult stage (Bailey, 1933; Bryan \& Smith, 1956; Jensen et al., 1992). Bailey (1933) observed that female WFT live longer than males and are more tolerant of lower temperatures. Since female WFT can reproduce either sexually or asexually, a lack of males in overwintering populations does not hamper rapid population increase once climatic conditions ameliorate in the spring. Yokoyama (1977) found that the period of bloom in table grapes coincided with a rapid increase in thrips populations and an increased dispersal of WFT from native plants. The adult WFT were attracted to the flowering grape clusters and their numbers increased rapidly, then declined sharply from the end of bloom. After bloom, however, the numbers of larvae in the clusters increased rapidly as the eggs laid during bloom started to hatch.

Many different methods can be used to sample and monitor thrips in fields, orchards and greenhouses (Lewis, 1997). Due to their small size and mobility, and since many species, including harmless ones, can occur in vineyards, sticky traps were considered to be the most appropriate monitoring method to be used by farmers. Sticky traps can be preserved in PVC pockets and can be transported easily to experts for the positive identification of economically important species before control decisions are taken. 
Many studies have evaluated coloured sticky traps for monitoring WFT. Moffitt (1964) found that white sticky traps attracted more WFT than yellow traps in pear orchards in southern California. Yudin et al. (1987) also found that white traps attracted the most thrips (96\% being WFT) in lettuce fields in Hawaii, but that blue and yellow traps also yielded high catches.

Vernon and Gillespie (1990) showed that the landing of WFT on coloured traps in cucumber greenhouses was governed by the quality (hue), quantity (intensity) and interactions (saturation) of the key wavelengths to which WFT is sensitive, namely UV ( $\lambda$ $350-360 \mathrm{~nm})$, blue $\left(\lambda_{\max } 440-450 \mathrm{~nm}\right)$ and yellow $\left(\lambda_{\max } 540-570\right.$ $\mathrm{nm})$. They found that more WFT females landed on blue traps than on yellow or non-UV-reflecting white traps, and concluded that non-UV-reflecting blue traps are best for monitoring WFT in greenhouses. According to Vernon and Gillespie (1990), the low numbers of WFT counted on blue traps by Yudin et al. (1987) was due to the low peak reflectance intensity of the blue traps that were used.

Gillespie and Vernon (1990) showed that blue traps captured more WFT females and that yellow traps caught more WFT males than any other trap colours in cucumber greenhouses where plants were grown on $2.1 \mathrm{~m}$ high trellises. The best height to place traps was at $2.4 \mathrm{~m}$, which is above the crop canopy and where colour intensity would be highest. Further work by Vernon and Gillespie (1995) showed that changing trap designs from flat to threedimensional shapes (e.g. cylinders, spheres) did not improve trapping efficiency. The lower cost and ease of handling make flat traps preferable for monitoring programmes.

Gaum and Giliomee (1994) demonstrated that blue traps with peak reflectance at about $460 \mathrm{~nm}$ were best for trapping WFT in South African greenhouses, while yellow traps with peak reflectance at $600 \mathrm{~nm}$ were best for trapping greenhouse whitefly (Trialeurodes vaporariorum).

The objectives of this study were to investigate efficient monitoring and the seasonal occurrence of WFT on table grapes, to confirm the type and degree of damage to table grape varieties and to determine overwintering sites and alternate host plants of WFT in the Hex River Valley.

\section{MATERIALS AND METHODS}

\section{Effect of trap position on trapping efficiency}

Sites were established in three commercial table grape vineyards, between seven and ten years old, in and near the Hex River Valley where producers reported high numbers of WFT. These included vineyards at Brugplaas (33.619 $774 \mathrm{~S}, 19.528161 \mathrm{E})$, Idlewinds (33.504 128 S, 19.579917 E) and Meiringshoop (33.448 658 S, 19.674957 E). Varieties grown included Sunred Seedless, a mid-season red table grape cultivar (Brugplaas), and Dauphine, a late-season white grape cultivar (Idlewinds, Meiringshoop). Each grower made a block of approximately 0.5 ha available for monitoring in which no insecticides were to be applied for thrips control.

Between August 2000 and April 2001, thrips were monitored with commercially available blue sticky traps, each measuring 100 mm x 290 mm (Bug trap from Agribiol ${ }^{\circledR}$, Box 16388, Vlaeberg 8018, South Africa). Four blue sticky traps were hung in each of two positions: suspended from the overhead trellising structure to hang either outside the canopy or under the vine canopy (Fig. 1). From 2000-08-10 to 2001-01-08, the sticky trap sheets were removed each week. Thereafter, the trap sheets were removed

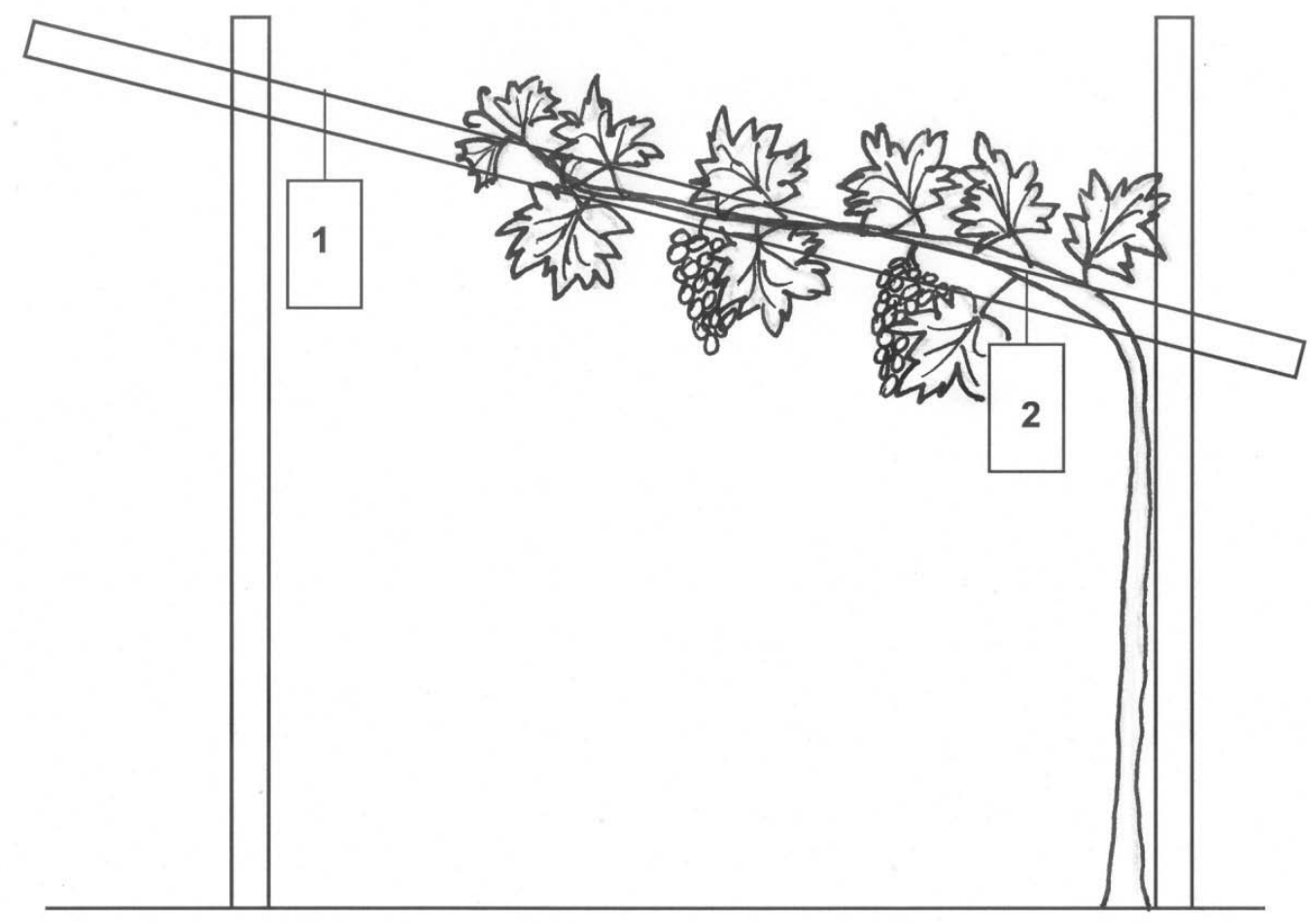

FIGURE 1

Positions of blue sticky traps: suspended from overhead trellising structure to hang outside the canopy (1), and suspended under the vine canopy (2). 
every two weeks until 2001-04-10. The traps were removed in the winter, as rain and cold rendered the sticky traps ineffective. Since male WFT do not contribute to halo spot damage, only the number of WFT females caught per trap was recorded. Thrips were identified with the aid of a key (Mound \& Kibby, 1998) and samples were sent to Dr L.A. Mound in Australia for confirmation of the identification.

\section{Seasonal occurrence}

The seasonal occurrence of WFT females was monitored at Brugplaas and Meiringshoop in the 2001/2002 season. Due to the removal of the vineyard at Idlewinds, it was substituted with a vineyard on a nearby farm, Grandview (33.502 857 S, 19.596338 E). This vineyard was planted with Red Globe, a mid-season red cultivar.

Four blue sticky traps were suspended from the trellising structure to hang outside the canopy in the trial sections of all three vineyards. Trap sheets were changed each week from 200107-23 to 2002-02-27, and every second week thereafter until 2002-03-19. During the 2002/2003 season, WFT females were monitored weekly from 2002-09-11 to 2003-02-25, and every two weeks thereafter until 2003-04-11 at Meiringshoop (Dauphine) and Grandview (Dauphine substituted for Red Globe).

On 2002-09-26 and 2002-10-17, shoot growth tips and pre-bloom grape clusters were sampled at Meiringshoop and Grandview to determine WFT presence. At each site, 25 prebloom grape clusters from different vines were selected randomly and tapped over a white plastic dish containing 70\% ethanol to provide a pooled sample. The contents of the dish were decanted into a honey jar and returned to the laboratory. The presence/ absence of WFT in the samples was recorded, but not the number of WFT per sample. Shoot growth tips (25 per site) were sampled at the same time using the same method.

\section{Damage assessments}

Shortly prior to harvest in the 2001/2002 and 2002/2003 seasons, 200 bunches, randomly distributed throughout the trial rows in each vineyard, were inspected and the number of halo spotdamaged berries per bunch was counted. Table grape producers have indicated that up to three damaged berries could still be removed from bunches without affecting the appearance of a bunch, but the removal of four or more damaged berries renders a bunch unsuitable for export and is therefore considered to be economic damage.

\section{Overwintering and alternate host plants}

On 2000-08-03, eight emergence traps were placed in each of the vineyards at Brugplaas and Meiringshoop to determine whether WFT overwinter in the weeds and leaf litter. Four traps were placed in the vine rows and four in the work rows between the vine rows in each vineyard. Circular PVC traps $(20 \mathrm{~cm}$ diameter, $10 \mathrm{~cm}$ high) were covered with plastic sheets taped over the PVC rim with masking tape. A sticky, non-toxic glue (Plantex $\left.{ }^{\circledR}\right)$ was applied to the lower sides of the plastic covering sheets to collect emerging thrips. The plastic sheets were exchanged weekly over a period of eight weeks from 2000-08-10 to 2000-09-28 and the number of WFT on them was recorded.

During August and September of each year, random samples were collected from flowering weeds in the trial vineyards. Each weed sample was shaken in a jar containing $70 \%$ ethanol to dislodge all thrips. After discarding the plant material, the thrips were extracted from the ethanol with a fine brush for identification. Weed species on which WFT were found were recorded. On 2002-08-07 a variety of winter weeds growing along the farm roads, as well as indigenous plants growing on the mountainside adjoining the vineyards at Grandview, were sampled. Between 10 and 15 flowers or flower heads of each plant were collected in honey jars and placed in a cooler box. Thrips were extracted for identification as described above. A sample of each plant was also collected separately and sent to the National Botanical Institute for identification.

\section{Statistical analysis}

Trap positions were assigned in a completely randomised manner, with position as treatment factor and four replicates for each sampling date and farm. Applicable analysis of variance was performed on counts and square root counts to accommodate the non-normality of residuals. A student's t-test with an LSD ( $p=$ 0.05 ) was performed to compare treatment means.

\section{RESULTS AND DISCUSSION}

\section{Effect of trap position on trapping efficiency}

The effect of trap position on catches of female WFT is presented in Fig. 2 and Table 1. From 2000-08-10 until 2000-10-11, while the grape canopy was still very sparse, the mean number of WFT per trap did not differ significantly between trap positions (Table 1), except on 2000-08-23 at Brugplaas. With a few exceptions, the traps hanging outside the canopy in full sunlight caught significantly more WFT than the traps hanging in the shadow under the increasingly dense canopy from 2000-10-05 (Brugplaas) to 2000-10-25 (Idlewinds and Meiringshoop). This concurs with the findings of Vernon and Gillespie (1990) and Gillespie and Vernon (1990) that traps are best placed above the crop canopy, where colour intensity would be highest.

\section{Seasonal occurrence}

Western flower thrips showed the same overall seasonal trend at all locations (Figs 2 to 4). Female WFT became active in the vineyards after the budding of the vines, and their numbers began to increase rapidly during the flowering period. However, during the 2000/2001 season, WFT numbers at Meiringshoop appeared to increase earlier (30 August) than in the subsequent two seasons. Occasionally, small increases in WFT numbers were observed towards the end of the growing season (Figs 2a to 2c), but since the grapes had been harvested by this stage there was no risk of economic damage. These results concur with population trends recorded by De Villiers and Pringle (2007) in table grape vineyards in the Hex River Valley during a study to develop a generic monitoring system for table grape pests. They found that thrips numbers began to increase from September or October and peaked in November.

The overall population levels of WFT were two orders of magnitude higher during the 2001/2002 season than during 2000/2001 (Figs 2 and 3). Furthermore, population levels declined in 2002/2003 compared to 2001/2002 (Figs 3 and 4), but at Meiringshoop farm the WFT level was still much higher than in 2000/2001 (Fig. 2c). In a subsequent study conducted in the same area, De Villiers and Pringle (2007) found similar differences in WFT seasonal activity and population levels between successive 
seasons. Variations in the timing of WFT seasonal activity and abundance between seasons can be attributed to various factors. Climatological conditions, particularly rainfall during winter and spring and temperature, have a direct effect on overwintering success and the early-season build-up of the WFT population in the following spring, but also have an impact on the abundance and quality of host plants (Kirk, 1997). The availability of overwintering host plants in and around vineyards, as well as cultural practices like the timing of herbicide applications and insecticide applications aimed at other grape pests during the growing season, could also affect WFT abundance in vineyards.

WFT adults were found in all the samples from the pre-bloom inflorescences and shoot tips. The presence of WFT on vines before flowering indicates that monitoring should start before flowering commences, particularly in vineyards with a history of WFT damage.

\section{Assessment of economic damage}

The results of the halo spot damage assessments are presented in Table 2. Although relatively high numbers of WFT were caught at Brugplaas and Grandview during flowering in 2001/2002 (Figs $3 \mathrm{a} \& \mathrm{~b}$ ), the percentage of bunches regarded as unsuitable for export (four or more damaged berries per bunch) was $0.5 \%$ and $0 \%$ respectively. Red and black grapes are more resistant to WFT oviposition damage due to the development of the pigment in the berry skins during ripening, which obscures the symptoms of halo spot (Jensen et al., 1992). However, 5\% and 9.5\% of bunches in

\section{TABLE 1}

ANOVA results for the effect of trap position on blue sticky trap catches of WFT (Frankliniella occidentalis) at Brugplaas, Grandview and Meiringshoop in the Hex River Valley, South Africa. For each sampling date at each farm, trap positions with the same letters do not differ significantly $(\mathrm{p}=0.05)$.

\begin{tabular}{|c|c|c|c|c|c|c|}
\hline \multirow{2}{*}{ DATE } & \multicolumn{2}{|c|}{ Brugplaas } & \multicolumn{2}{|c|}{ Idlewinds } & \multicolumn{2}{|c|}{ Meiringshoop } \\
\hline & Trap pos. $1^{*}$ & Trap pos. $2 *$ & Trap pos. 1 & Trap pos. 2 & Trap pos. 1 & Trap pos. 2 \\
\hline $2000 / 08 / 10$ & $\mathrm{a}$ & $\mathrm{a}$ & - & - & - & - \\
\hline $2000 / 08 / 17$ & $\mathrm{a}$ & a & - & - & - & - \\
\hline $2000 / 08 / 23$ & $\mathrm{a}$ & $\mathrm{b}$ & - & - & $\mathrm{a}$ & $\mathrm{a}$ \\
\hline $2000 / 08 / 31$ & $\mathrm{a}$ & $\mathrm{a}$ & $\mathrm{a}$ & $\mathrm{a}$ & $\mathrm{a}$ & $\mathrm{a}$ \\
\hline $2000 / 09 / 06$ & $-^{* *}$ & - & $\mathrm{a}$ & $\mathrm{a}$ & a & $\mathrm{a}$ \\
\hline $2000 / 09 / 14$ & $\mathrm{a}$ & $\mathrm{a}$ & $\mathrm{a}$ & $\mathrm{a}$ & $\mathrm{a}$ & $\mathrm{a}$ \\
\hline $2000 / 09 / 21$ & $\mathrm{a}$ & $\mathrm{a}$ & $\mathrm{a}$ & $\mathrm{a}$ & a & $\mathrm{a}$ \\
\hline $2000 / 09 / 28$ & $\mathrm{a}$ & $\mathrm{a}$ & - & - & $\mathrm{a}$ & $\mathrm{a}$ \\
\hline $2000 / 10 / 05$ & $\mathrm{a}$ & $\mathrm{b}$ & $\mathrm{a}$ & $\mathrm{a}$ & $\mathrm{a}$ & $\mathrm{a}$ \\
\hline $2000 / 10 / 11$ & $\mathrm{a}$ & $\mathrm{a}$ & $\mathrm{a}$ & $\mathrm{a}$ & $\mathrm{a}$ & $\mathrm{a}$ \\
\hline $2000 / 10 / 17$ & $\mathrm{a}$ & $\mathrm{b}$ & $\mathrm{a}$ & $\mathrm{a}$ & $\mathrm{a}$ & $\mathrm{a}$ \\
\hline $2000 / 10 / 25$ & a & $\mathrm{b}$ & $\mathrm{a}$ & $\mathrm{b}$ & a & $\mathrm{b}$ \\
\hline $2000 / 11 / 01$ & $\mathrm{a}$ & $\mathrm{b}$ & $\mathrm{a}$ & $\mathrm{a}$ & $\mathrm{a}$ & $\mathrm{b}$ \\
\hline $2000 / 11 / 09$ & a & $\mathrm{b}$ & $\mathrm{a}$ & $\mathrm{b}$ & a & $\mathrm{a}$ \\
\hline $2000 / 11 / 16$ & $\mathrm{a}$ & $\mathrm{b}$ & $\mathrm{a}$ & $\mathrm{b}$ & $\mathrm{a}$ & $\mathrm{a}$ \\
\hline $2000 / 11 / 23$ & $\mathrm{a}$ & $\mathrm{a}$ & $\mathrm{a}$ & $\mathrm{b}$ & $\mathrm{a}$ & $\mathrm{b}$ \\
\hline $2000 / 11 / 30$ & $\mathrm{a}$ & $\mathrm{b}$ & $\mathrm{a}$ & $\mathrm{a}$ & $\mathrm{a}$ & $\mathrm{b}$ \\
\hline $2000 / 12 / 07$ & $\mathrm{a}$ & $\mathrm{a}$ & $\mathrm{a}$ & $\mathrm{a}$ & a & $\mathrm{b}$ \\
\hline $2000 / 12 / 14$ & $\mathrm{a}$ & $\mathrm{b}$ & $\mathrm{a}$ & $\mathrm{a}$ & $\mathrm{a}$ & $\mathrm{b}$ \\
\hline $2000 / 12 / 21$ & a & $\mathrm{b}$ & $\mathrm{a}$ & $\mathrm{b}$ & a & $\mathrm{b}$ \\
\hline $2001 / 01 / 08$ & $\mathrm{a}$ & $\mathrm{a}$ & $\mathrm{a}$ & $\mathrm{b}$ & $\mathrm{a}$ & $\mathrm{b}$ \\
\hline $2001 / 01 / 18$ & $\mathrm{a}$ & $\mathrm{b}$ & $\mathrm{a}$ & $\mathrm{b}$ & $\mathrm{a}$ & $\mathrm{b}$ \\
\hline $2001 / 01 / 31$ & $\mathrm{a}$ & $\mathrm{b}$ & $\mathrm{a}$ & $\mathrm{b}$ & $\mathrm{a}$ & $\mathrm{b}$ \\
\hline $2001 / 02 / 13$ & a & $\mathrm{b}$ & $\mathrm{a}$ & $\mathrm{b}$ & $\mathrm{a}$ & $\mathrm{a}$ \\
\hline $2001 / 03 / 01$ & $\mathrm{a}$ & $\mathrm{a}$ & $\mathrm{a}$ & $\mathrm{b}$ & a & $\mathrm{b}$ \\
\hline $2001 / 03 / 20$ & $\mathrm{a}$ & $\mathrm{b}$ & $\mathrm{a}$ & $\mathrm{b}$ & $\mathrm{a}$ & $\mathrm{b}$ \\
\hline $2001 / 04 / 10$ & $\mathrm{a}$ & a & $\mathrm{a}$ & $\mathrm{b}$ & a & $\mathrm{a}$ \\
\hline
\end{tabular}

*Trap position 1: suspended from overhead trellising structure to hang outside the canopy; Trap position 2: suspended under the vine canopy (see Fig. 1).

**No analysis possible due to missing traps at one or both trap positions. 
the Sunred Seedless and Red Globe vineyards respectively had between one and three berries with visible halo spot damage. Halo spot damage was more visible on the lighter coloured berries of Dauphine, which have less pigment.

At Meiringshoop the high number of WFT females recorded during flowering in the 2001/2002 season (Fig. 3c) resulted in $14.5 \%$ economic halo spot damage in the bunches assessed. During the 2002/2003 season, the number of WFT females recorded during flowering was much lower than during the previous season (Fig. 4b), but $8 \%$ of the bunches assessed prior to harvest still exhibited economic damage. These results show that economic damage can occur even when trap catches during flowering are relatively low. Weather conditions not conducive to flight can lower trap catches, whilst WFT oviposition activity in the flowering bunches continues. This would explain the apparent discrepancy between trap catches early in the season and halo spot damage to the berries.

The Dauphine vineyard at Grandview, on the other hand, exhibited a very different trend. The numbers of western flower thrips during flowering in 2002/2003 (Fig. 4a) were comparable to those at Meiringshoop (Fig. 4b), but no bunches were found to have economic damage prior to harvest. However, $15.5 \%$ of the bunches did have between one and three berries with halo spot damage.

According to Jensen et al. (1992), feeding by WFT can cause berry scarring, as well as shoot stunting of and foliar damage to
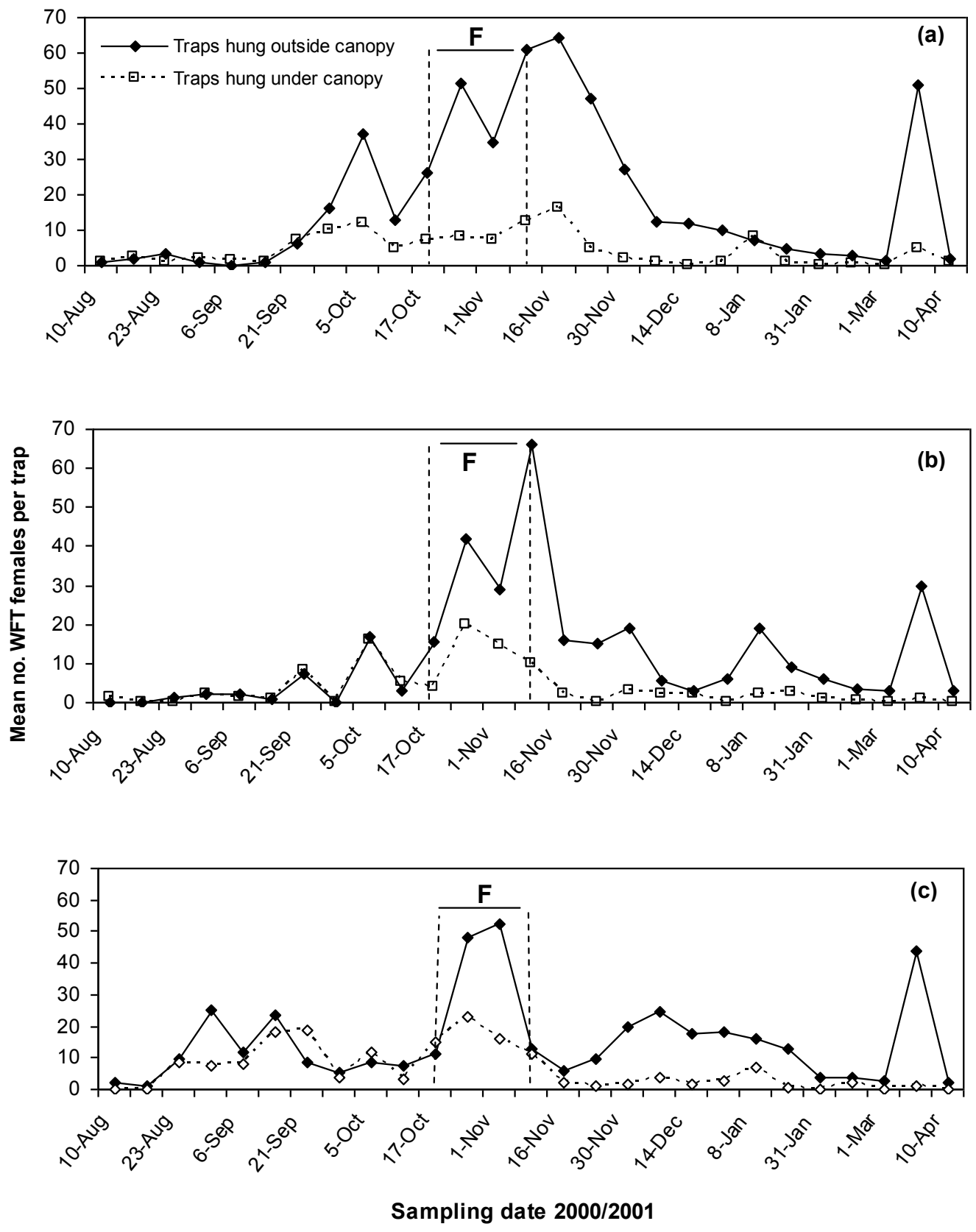

FIGURE 2

Seasonal occurrence of Frankliniella occidentalis monitored with two blue sticky traps suspended from trellising wires outside the vine canopy and two suspended under the vine canopy in three table grape vineyards at (a) Brugplaas, (b) Idlewinds and (c) Meiringshoop during 2000/2001. F = flowering period. 
table grapes. None of these symptoms was recorded in any of the trial vineyards for the duration of this study. Shoot stunting and scarring have been observed in vineyards in the warmer, northern regions of the Lower Orange River Valley and Mpumalanga when WFT was present (personal observation). However, the possibility that other thrips species, like Scirtothrips aurantii, may be contributing to this damage cannot be excluded. In these areas it is important to continue monitoring for WFT for the duration of the growing season.

The data from the various trial vineyards showed no consistent relationship between economic damage at harvest and WFT numbers on sticky traps during flowering and berry set. This may be partly because trap catches largely reflect WFT flight in vineyards. Early season trap catches probably underestimate the WFT population levels in the grape flowering clusters, particularly when weather conditions are unfavourable for thrips flight. De Villiers and Pringle (2007), on the basis of combined data from 12 vineyards, found that the number of thrips on blue sticky traps gave a good indication of bunch damage four weeks later. However, this was not always the case for data from individual blocks. They concluded that bunch damage predictions can only be made in general and not for individual blocks. Because of the difficulty
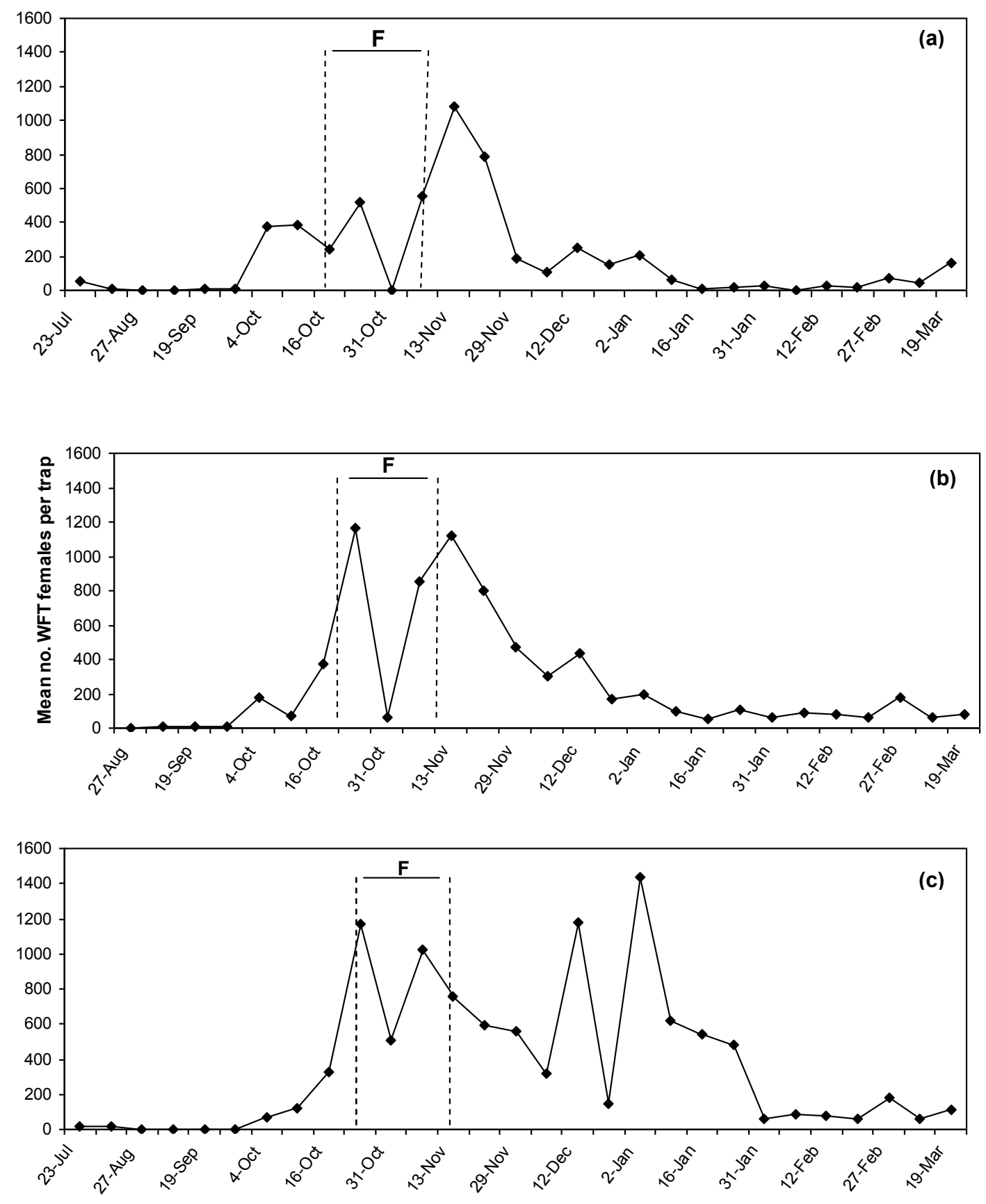

Sampling date $2001 / 2002$

FIGURE 3

Seasonal occurrence of Frankliniella occidentalis monitored with four blue sticky traps suspended outside the vine canopy in three table grape vineyards at (a) Brugplaas, (b) Grandview and (c) Meiringshoop during 2001/2002. F = flowering period. 


\section{TABLE 2}

Pre-harvest assessments of oviposition damage by western flower thrips (Frankliniella occidentalis) on table grapes at Brugplaas, Grandview and Meiringshoop in the Hex River Valley, South Africa ( $\mathrm{n}=200$ bunches per vineyard).

\begin{tabular}{|c|c|c|c|c|c|c|}
\hline \multirow[b]{2}{*}{ Year } & \multirow[b]{2}{*}{$\begin{array}{l}\text { Farm } \\
\text { Cultivar }\end{array}$} & \multicolumn{4}{|c|}{ No. bunches with halo spot-damaged berries } & \multirow[b]{2}{*}{$\begin{array}{c}\% \text { Bunches } \\
\text { with economic } \\
\text { damage }^{*}\end{array}$} \\
\hline & & $\begin{array}{c}0 \text { damaged } \\
\text { berries/bunch }\end{array}$ & $\begin{array}{c}1 \text { damaged } \\
\text { berry/bunch }\end{array}$ & $\begin{array}{l}2-3 \text { damaged } \\
\text { berries/bunch }\end{array}$ & $\begin{array}{c}\geq 4 \text { damaged } \\
\text { berries/bunch }\end{array}$ & \\
\hline \multirow[t]{3}{*}{2002} & $\begin{array}{c}\text { Brugplaas } \\
\text { Sunred Seedless }\end{array}$ & 189 & 8 & 2 & 1 & 0.5 \\
\hline & $\begin{array}{l}\text { Grandview } \\
\text { Red Globe }\end{array}$ & 181 & 17 & 2 & 0 & 0 \\
\hline & $\begin{array}{l}\text { Meiringshoop } \\
\text { Dauphine }\end{array}$ & 77 & 37 & 57 & 29 & 14.5 \\
\hline \multirow[t]{2}{*}{2003} & $\begin{array}{l}\text { Grandview } \\
\text { Dauphine }\end{array}$ & 169 & 25 & 6 & 0 & 0 \\
\hline & $\begin{array}{l}\text { Meiringshoop } \\
\text { Dauphine }\end{array}$ & 116 & 40 & 28 & 16 & 8 \\
\hline
\end{tabular}

*Bunches with four or more berries showing WFT halo spot damage were considered unsuitable for export.
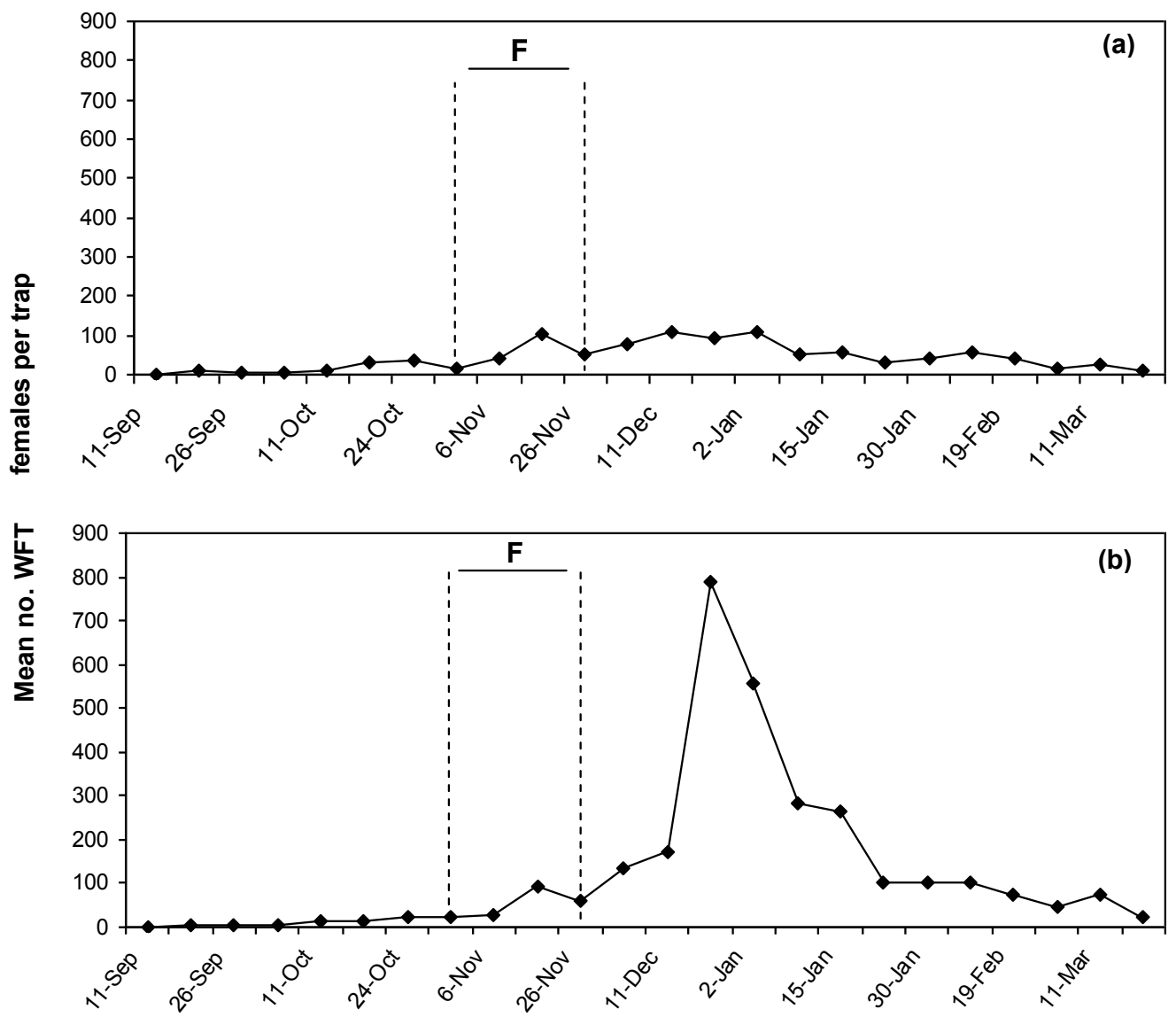

Sampling date $2002 / 2003$

FIGURE 4

Seasonal occurrence of Frankliniella occidentalis monitored with four blue sticky traps suspended outside the vine canopy in two table grape vineyards at (a) Grandview and (b) Meiringshoop during 2002/2003. F = flowering period. 
TABLE 3

Plants from which adult western flower thrips (Frankliniella occidentalis) were recovered in the Hex River Valley, South Africa.

\begin{tabular}{|c|c|c|c|}
\hline & Botanical name & Family & Common name \\
\hline \multirow{6}{*}{ Weeds/cover crop } & Echium plantagineum $\mathrm{L}$. & Boranginaceae & Patterson's curse \\
\hline & Malva parviflora $\mathrm{L}$. & Malvaceae & Small mallow \\
\hline & Erodium moshantum L'Her. & Geraniacaea & Musk Herons Bill \\
\hline & Sonchus oleraceus L. & Compositae & Sowthistle \\
\hline & Raphanus raphanistrum $\mathrm{L}$. & Cruciferae & Wild radish \\
\hline & Medigaco sativa $\mathrm{L}$. & Leguminosae & Lucerne \\
\hline \multirow{5}{*}{ Indigenous plants } & Euryops tenuissimus (L.) DC. & Compositae & Resin bush \\
\hline & Leyssera gnaphalioides (L.) L. & Compositae & Yellow flower tea \\
\hline & Helichrysum moeserianum Thell. & Compositae & \\
\hline & Athanasia trifurcata (L.) L. & Compositae & Kouter bush \\
\hline & Cyanella hyacinthoides $\mathrm{L}$. & Tecophilaeaceae & Lady's hand \\
\hline
\end{tabular}

of identifying WFT on sticky traps they did not recommend the use of sticky traps to predict bunch damage. Both studies indicate that sticky traps should only be used to determine the presence or absence of WFT in vineyards.

\section{Emergence traps and alternate hosts}

Emergence traps placed in the vineyards at Brugplaas and Meiringshoop at the beginning of spring yielded very few thrips. From 2000-08-10 to 2000-09-28, the eight emergence traps at Brugplaas yielded a total of 13 WFT, while only nine WFT were collected at Meiringshoop in the same period.

Adult western flower thrips were collected from the flowers of a number of weed species growing in and around the trial vineyards and also from the flowers of several indigenous plants (Table 3). The sampled indigenous flowers represent only a small portion of the indigenous plants in the Hex River Valley. Further investigation is likely to add more species to the list of local plants utilised by WFT. This list already includes many plants common in farm and home gardens.

The results from the emergence traps suggest that thrips pupating in leaf litter and overwintering on non-flowering winter weeds are not the major source of WFT infestation in vineyards. The fact that WFT were found on several weed and indigenous plant species growing outside the vineyards suggests that there could be a constant influx of thrips into vineyards from the surrounding vegetation during the growing season. Bailey (1933) reported that WFT and many other thrips species in California move onto crops in the early summer as their wild hosts begin drying up. When cover crops are ploughed under and alfalfa fields are mowed, WFT are also forced to move to other host plants. According to Jensen et al. (1992), WFT may move into vineyards when weeds are disked in or when natural vegetation dries up in the summer. Pearsall and Myers (2001) also found that WFT moved readily from weeds, wild flowers and sagebrush to oviposit in nectarine blossoms during the spring in the dry central interior of British Columbia, Canada as the wild hosts became dry and less attractive.
These findings indicate that merely eliminating flowering host weeds from vineyards will not be sufficient to prevent WFT infestation during the season.

\section{CONCLUSIONS}

Commercially available blue sticky traps, suspended to hang outside the vine canopy in full sunlight, can be used to monitor for the presence of WFT in table grape vineyards. Monitoring should commence before flowering, as soon as the first inflorescences are formed. In vineyards with a history of WFT damage, control measures should be considered as soon as the presence of WFT is confirmed in order to prevent halo spot damage. Since the efficacy of chemical control with contact pesticides can be compromised by the influx of WFT from the surrounding environment, future research should look at methods to protect vulnerable parts of the crop from WFT feeding and oviposition, rather than eliminating WFT from vineyards.

\section{LITERATURE CITED}

Bailey, S.F., 1933. A contribution to the knowledge of the western flower thrips, Frankliniella californica (Moulton). J. Econ. Entomol. 26, 836-840.

Bryan, D.E. \& Smith, R.F., 1956. The Frankliniella occidentalis (Pergande) complex in California (Thysanoptera: Thripidae). Univ. Calif. Publs Ent. 10, 359410 .

De Villiers, M. \& Pringle, K.L., 2007. Seasonal occurrence of vine pests in commercially treated vineyards in the Hex River Valley in the Western Cape Province, South Africa. Afr. Ent. 15, 241-260.

Gaum, W.G. \& Giliomee, J.H., 1994. Preference of western flower thrips, Frankliniella occidentalis (Thysanoptera: Thripidae), and greenhouse whitefly, Trialeurodes vaporariorum (Hemiptera: Aleyrodidae), for differently coloured sticky traps. J. S. Afr. Soc. Hort. Sci. 4, 39-41.

Giliomee, J.H., 1989. First record of western flower thrips, Frankliniella occidentalis (Pergande) (Thysanoptera: Thripidae) from South Africa. J. ent. Soc. sth. Afr. 52, 179-180.

Gillespie, D.R. \& Vernon, R.S., 1990. Trap catch of western flower thrips, Frankliniella occidentalis (Thysanoptera: Thripidae), as affected by colour and height of sticky traps in greenhouses. J. Econ. Entomol. 83, 971-975. 
Jensen, F., 1973. Timing of halo spotting by flower thrips on table grapes. Calif. Agric. 27, 6-8.

Jensen, F.L., Flaherty, D.L. \& Luvisi, D.A., 1992 ( $2^{\text {nd }}$ ed $)$. Thrips. In: Flaherty, D.L., Christensen, L.P., Lanini, W.T., Marois, J-J., Phillips, P.A. \& Wilson, L.T. (eds). Grape pest management. Division of Agriculture and Natural Resources, University of California. pp. 193-201.

Kirk, W.D.J., 1997. Distribution, abundance and population dynamics. In: Lewis, T. (ed). Thrips as crop pests. CAB International, Oxon, New York. pp. 217 - 275.

Kirk, W.D.J. \& Terry, I., 2003. The spread of western flower thrips Frankliniella occidentalis (Pergande). Agr. Forest Entomol. 5, 301-310.

Lewis, T., 1997. Field and laboratory techniques. In: Lewis, T. (ed). Thrips as crop pests. CAB International, Oxon, New York. pp. 435 - 475

Marais, E., 2000. Status of western flower thrips research on table grapes in South Africa. Decid. Fruit Grow. 50, 15.

Moffitt, H.R., 1964. A color preference of the western flower thrips, Frankliniella occidentalis. J. Econ. Entomol. 57, 604-605.

Mound, L.A. \& Kibby, G., 1998 (2 $2^{\text {nd }}$ ed). Thysanoptera: an identification guide. CAB International, Oxon, New York.

Pearsall, I.A. \& Myers, J.H., 2001. Spatial and temporal patterns of dispersal of western flower thrips (Thysanoptera: Thripidae) in nectarine orchards in British Columbia. J. Econ. Entomol. 94, 831-843.
Roditakis, E. \& Roditakis, N.E., 2007. Assessment of the damage potential of three thrips species on white variety table grapes - In vitro experiments. Crop Protection 26, 476-483.

Schwartz, A., 1987. Thrips in table grapes. Viticulture and Oenology F 27. Farming in South Africa.

Schwartz, A., 1988. Population dynamics of Thrips tabaci Lindeman (Thysanoptera: Thripidae) on table grapes. S. Afr. J. Enol. Vitic. 9(1), 19-21.

Vernon, R.S. \& Gillespie, D.R., 1990. Spectral responsiveness of Frankliniella occidentalis (Thysanoptera: Thripidae) determined by trap catches in greenhouses. Environ. Entomol. 19, 1229-1241.

Vernon, R.S. \& Gillespie, D.R., 1995. Influence of trap shape, size, and background colour on captures of Frankliniella occidentalis (Thysanoptera: Thripidae) in a cucumber greenhouse. J. Econ. Entomol. 88, 288-293.

Yokoyama, V.Y., 1977. Frankliniella occidentalis and scars on table grapes. Environ. Entomol. 6, 25-30.

Yudin, L.S., Mitchell, W.C. \& Cho, J.J., 1987. Color preference of thrips (Thysanoptera: Thripidae) with reference to aphids (Homoptera: Aphididae) and leafminers in Hawaiian lettuce farms. J. Econ. Entomol. 80, 51-55. 